\title{
Cost-utility analysis of a dance intervention for adolescent girls with internalizing problems
}

\author{
Anna Philipsson ${ }^{1 *}$, Anna Duberg ${ }^{2,3}$, Margareta Möller $^{2,3}$ and Lars Hagberg ${ }^{1,2,3}$
}

\begin{abstract}
Background: The increasing prevalence of psychological health problems among adolescent girls is alarming. Knowledge of beneficial effects of physical activity on psychological health is widespread. Dance is a popular form of exercise that could be a protective factor in preventing and treating symptoms of depression. The aim of this study was to assess the cost-effectiveness of a dance intervention in addition to usual school health services for adolescent girls with internalizing problems, compared with usual school health services alone.
\end{abstract}

Methods: A cost-utility analysis from a societal perspective based on a randomized controlled intervention trial was performed. The setting was a city in central Sweden with a population of 130000 . A total of 112 adolescent girls, 1318 years old, with internalizing problems participated in the study. They were randomly assigned to intervention $(n=$ 59) or control $(n=53)$ group. The intervention comprised dance twice weekly during eight months in addition to usual school health services. Costs for the stakeholder of the intervention, treatment effect and healthcare costs were considered. Gained quality-adjusted life-years (QALYS) were used to measure the effects. Quality of life was measured with the Health Utility Index Mark 3. Cost-effectiveness ratios were based on the changes in QALYs and net costs for the intervention group compared with the control group. Likelihood of cost-effectiveness was calculated.

Results: At 20 months, quality of life had increased by 0.08 units more in the intervention group than in the control group $(P=.04)$, translating to 0.10 gained QALYs. The incremental cost-effectiveness ratio was USD $\$ 3,830$ per QALY and the likelihood of cost-effectiveness was $95 \%$.

Conclusions: Intervention with dance twice weekly in addition to usual school health services may be considered cost-effective compared with usual school health services alone, for adolescent girls with internalizing problems.

Trial registration: Name of the trial registry: "Influencing Adolescent Girls' With Creative Dance Twice Weekly" Trial registration number: NCT01523561

Keywords: Internalizing problems, Adolescent girls, Physical activity, Dance, Cost-utility analysis

\section{Background}

A trend of increasing mental health problems and psychosomatic symptoms among children and adolescents has been shown in recent years [1,2]. Several indicators demonstrate that internalizing problems, such as anxiety and depression, are particularly common among young women, reported by as many as 20 percent of adolescent girls, $[2,3]$. The number of adolescent girls (10-19 years old), diagnosed in institutional care with depression and anxiety is alarming; it has more than tripled in Sweden

\footnotetext{
* Correspondence: anna.philipsson@orebroll.se

'Department of Community Medicine and Public health, Örebro County

Council, P.O. Box 1613, Örebro SE-70116, Sweden

Full list of author information is available at the end of the article
}

during the past ten years [4]. Internalizing problems may impose high societal costs, disability and decreased quality of life for individuals [5-7]. Research on interventions targeting adolescent girls is scarce and there is a great need for effective interventions [8]. Furthermore, the society has the right to demand that interventions offered are based on scientific evidence and that they are cost-effective [9-11].

The School Health Services comprise a physician and a school nurse and its aim is to "monitor the students' development, to protect and improve their mental and physical health, and to try to instill healthy living habits in them" during the whole school-age period from 6 to 19 years of age [12]. Visits to the School Health Services by

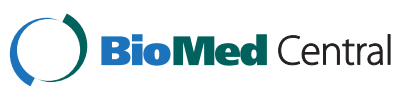


the students, especially girls, are common and research shows that most of the visits to the school nurse are caused by headache, depression, back or neck problems, or by students who just "want to talk" [13]. The activities of the School Health Services are stated in the Education Act and are also included in The principles of health care of the National Board of Health and Welfare [14,15].

Studies show that physical exercise in general can be an active strategy to prevent and treat depression and anxiety and to promote positive thoughts and feelings [16-19]. Dance is a popular form of exercise for girls $[20,21]$. Research has also shown that dance could be a protective factor in preventing and treating symptoms of depression [22,23]. No economic evaluation has been found of dance as an intervention to prevent or treat internalizing problems.

The aim of this study was to assess the cost-effectiveness of a dance intervention in addition to usual school health services for adolescent girls with internalizing problems, compared with usual school health services alone.

\section{Methods}

\section{Intervention trial}

A complete description of the intervention trial has been published elsewhere [24].

\section{Study design}

The study was a prospective, randomized and controlled intervention trial with an intervention group who received dance classes twice weekly during 8 months, and a control group who received standard prevention and care. Participants were followed up five times during the study period (Figure 1). The Regional Ethical Review Board in Uppsala, Sweden has approved the trial (DNR 2008/134).

\section{Study population}

Girls 13 to 18 years old with internalizing problems, i.e. often experiencing feelings of stress, who visited the school nurse frequently or who had recurrent psychosomatic symptoms, were enrolled. Persistent feelings of tiredness, being worried, in low spirit or low mood were also inclusion criteria. Exclusion criteria were severe hearing impairment, mental retardation, difficulties in speaking or writing in the Swedish language, and advice against inclusion by the Children and Adolescent Psychiatry or a psychologist [24].

The dance intervention was conducted twice in order to offer more girls the intervention and to overcome the limit in resources, such as the number of dance instructors and studio availability. Hence, participants

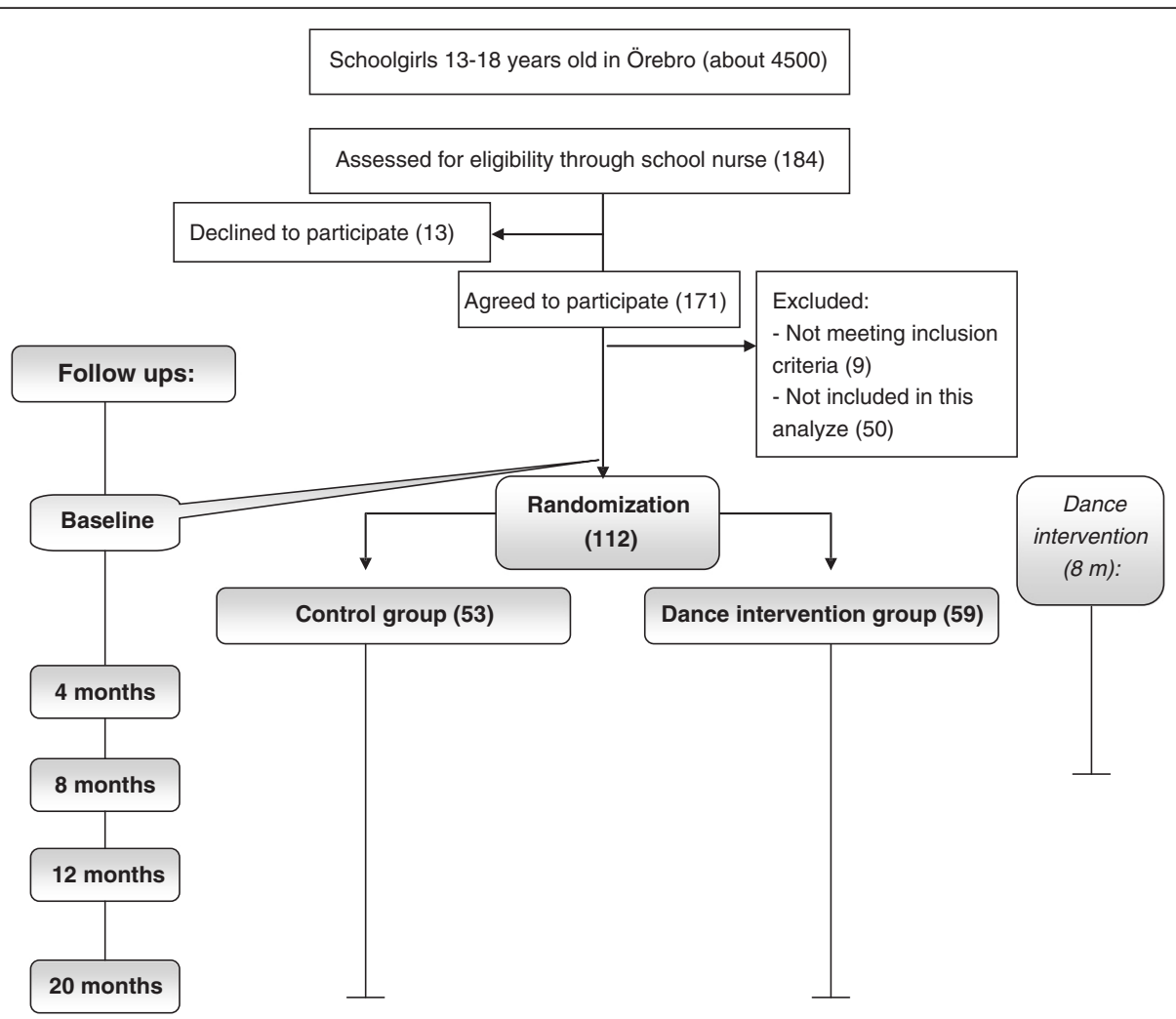

Figure 1 Flowchart. Participants responded to a baseline questionnaire at the start of the study. Randomization was carried out, and the 8month dance intervention was initiated. Follow-ups for both groups were at 4, 8, 12, and 20 months after baseline. 
were enrolled and randomized on two different occasions. However, the analyses in this article include only the girls who participated in the intervention in the first year and the new intake girls who participated in the intervention during the second year. The girls who were randomized to the control group in the first year and crossed over to the intervention group in the second year, were excluded from the analyses. The study took place in a city in central Sweden with 130000 citizens [24].

A total of 112 participants were included in the analyses. Baseline characteristics are described in Table 1. An external statistician randomly allocated the participants to the intervention group $(n=59)$ or the control group $(n=53)$. The reason for allocating more participants to the intervention group was that we wanted to make sure that there would be a sufficient number of girls to fill up the dance groups. There was no blinding. All self-reported data were entered into the computer by a research assistant [24].

\section{Dance intervention}

The intervention comprised dance classes twice weekly during 8 months. It was pronounced from the start of the intervention that the focus was on joy and not on performance. The dance classes consisted of different dance themes and each session contained warm-up, creative group practice, dance routine and stretch. Each session was ended with relaxation [24].

\section{Usual school health services}

Usual school health services comprised conventional prevention and care provided by the school nurse according to the guidelines for the School Health Services in the county of Örebro [25]. The objective of these guidelines is to clarify the routines and the guiding principles to ensure equal treatment of the students. Another objective is to define evidence-based methods for the School Health Services according to the Health and Medical Service Act [15]. Both the intervention and control group had access to this conventional prevention and care.

\section{Economic evaluation}

The economic evaluation was performed as a cost-utility analysis from a societal perspective, using individual data [26]. In the analysis costs for the stakeholder of the intervention, health effect and savings in health care use were considered (Table 2). Gained quality-adjusted lifeyears (QALYs) were used to measure the effects. Costeffectiveness ratios were based on the changes in quality of life (QOL) and net costs for the intervention group compared with those for the control group. QOL was measured with the Health Utility Index Mark 3 (HUI3) [27]. The time period measured was 20 months. Health effects and savings beyond 12 months were discounted by $3 \%$.

\section{Description of costs}

Cost estimates were derived through contacts with personnel in the project and in the head office of the School Health Services [28-31]. The cost estimates considered in this analysis were: (1) the cost of the dance classes; (2) the cost of using selected healthcare resources, i.e. visits to the school nurses (self-reported values). Number of visits was compared with the baseline value at all follow-ups. All cost estimates, however, included overhead costs and were converted from Swedish krona (SEK) to USD using an approximated exchange rate of $1 \mathrm{SEK}=0.15 \mathrm{USD}$. The prices are valid for 2011.

\section{Description of health effect}

The Health Utilities Index Mark 3 (HUI3) [27,32,33] was used to measure and ascribe values to the participants' health states. The HUI3 is a pre-scored health status instrument, originally developed in Canada, that asks the patient questions about his or her overall health status and health-related quality of life The HUI3 assesses eight

Table 1 Baseline characteristics

\begin{tabular}{lcc}
\hline Variable & $\begin{array}{c}\text { Intervention } \\
\text { group }(\mathbf{n}=\mathbf{5 9 )}\end{array}$ & $\begin{array}{c}\text { Control group } \\
(\mathbf{n}=\mathbf{5 3}) \\
\mathbf{N}(\%)\end{array}$ \\
\hline Age $^{a}$ 13-14 years & $\mathbf{N}(\%)$ & $13(25)$ \\
Age 15-16 years & $8(13)$ & $23(43)$ \\
Age 17-18 years & $27(46)$ & $17(32)$ \\
Born in Sweden & $24(41)$ & $49(93)$ \\
Lives with both parents & $55(93)$ & $30(57)$ \\
Rates their health as poor or very poor & $24(41)$ & $3(6)$ \\
Experiences feeling of stress frequently & $8(14)$ & $28(53)$ \\
Participated in dancing before start of study & $41(69)$ & $36(68)$ \\
\hline
\end{tabular}

${ }^{\mathrm{a}}$ Mean for both intervention group and control group: 16 years. 
Table 2 Factor, variable and method for the economic evaluation

\begin{tabular}{lll}
\hline \multicolumn{1}{c}{ Factor } & \multicolumn{1}{c}{ Variable } & \multicolumn{1}{c}{ Method } \\
$\begin{array}{l}\text { Intervention } \\
\text { costs }\end{array}$ & $\begin{array}{l}\text { Intervention costs for the } \\
\text { stakeholder }\end{array}$ & $\begin{array}{l}\text { Individual costs were calculated based on the number of participants in the intervention group, and } \\
\text { estimated fractions of costs for dance teacher, rent, equipment and overhead [28,29]. } \\
\text { Health care } \\
\text { savings }\end{array}$ \\
$\begin{array}{llll}\text { Health care savings for } \\
\text { stakeholder }\end{array}$ & $\begin{array}{l}\text { Savings for health care were estimated based on self-reported data from the last term before baseline } \\
\text { and } 20 \text { months use after the start of the intervention. Number of visits was compared with the baseline } \\
\text { value at all follow-ups. Costs for each visit were calculated based on estimated costs for salary, etc } \\
\text { [30,31]. and total number of visits to the school nurse. }\end{array}$ \\
HUI3
\end{tabular}

preference-based attributes of function (health status) that are believed to contribute to quality of life: Ambulation, Dexterity, Speech, Vision, Hearing, Cognition, Emotion, and Pain. Each attribute has five or six levels of ability/disability. These levels are ordered from normal function (not impaired, or a ranking of 1 ) to severely impaired (a ranking of 5 or 6 , depending on the attribute). All attributes are structurally independent, which means that all combinations of levels in the system are possible, allowing descriptions of 972000 health states $[27,32,33]$. In the present study, the attributes emotion, cognition and pain were determined to be the most suitable for the study subject [27]. The time frame captured was 'current health' (no specified period). Single questions were used for each attribute. The original version of the HUI3 questionnaire was developed in English [27,32,33]. For the present study, the original Canadian questionnaire was translated to Swedish by a professional translator, after which another translator translated it back to English. The original and the backtranslated English versions were compared and checked for discrepancies, after which the Swedish questionnaire was revised.

Gained QALYs were calculated from the difference in QOL between the intervention and control groups at all follow-ups. The overall utility score from the HUI3 was used as the quality adjustment factor for calculating QALYs gained. Differences were assumed to develop linearly between follow-ups.

\section{Cost-effectiveness}

Cost-effectiveness ratio (ICER) is expressed as Costs savings / QALY = ICER.

Cost-effectiveness is often calculated using the mean difference in costs and effects, and is based on comparison between two or more possible treatment options. Using mean values for cost-effectiveness ratios is associated with uncertainty. In the analysis, this uncertainty is handled with the Net Monetary Benefit (NMB) method [34,35]. This method is based on health effects (QALYs) given a value, on individual level, of that amount of money decision makers are willing to pay for a gained QALY. When all data are expressed in money, it is possible to calculate the likelihood that an intervention is cost-effective in relation to a competing intervention.

\section{Statistical methods}

Data were analyzed according to the intention-to-treat principle, meaning that all study participants were analyzed in the study group that they were randomized to. Analyses of effect size within each group were performed using paired-samples t tests. Differences between groups were analyzed with independent-samples $t$ tests. Individual values were used for savings in healthcare, gained QALY and costs in intervention and control groups. Significance level was set at $P<.05$.

A scatter plot of 5000 bootstrapped incremental costeffectiveness ratios was created by repeatedly drawing a random sample with replacement, using parameters estimated from the randomized controlled intervention trial. This produced estimates of the probability that the intervention was cost-effective using several thresholds of willingness to pay for a QALY. Minitab 15.0 was used for this process. Results are presented in a costeffectiveness acceptability curve [36].

If data were missing the last observation carried forward approach was used [37-39]. This implies that the last value observed is imputed.

\section{Sensitivity analyses}

We conducted sensitivity analyses. Cost-effectiveness was also calculated without savings, with 50\% higher costs and with $50 \%$ reduced effect on QALYs. For NMB, we repeated the estimation of net monetary benefit with two different amounts for how much a gained QALY can cost.

\section{Results}

112 subjects were included in the study and 93 (83\%) of them completed the 20-month follow-up.

\section{Intervention costs}

The mean cost for one girl participating in one dance session was USD \$25 (Table 3). Based on that value the mean cost for the whole dance intervention was USD \$670 per participant. As the control group didn't receive any dance intervention there were no such costs for them. 
Table 3 Costs per each dance session per participant (USD)

\begin{tabular}{ll}
\hline Type of cost for the intervention & Cost \\
\hline Dance teacher & $146^{\mathrm{a}}$ \\
Rental for dance studio & 8.1 \\
Equipment (music and continuation courses) & 0.2 \\
Further education for the dance teachers & 0.2 \\
Overhead costs 13\% & 1.9 \\
Total costs per each dance session per participant & 25 \\
\hline
\end{tabular}

${ }^{a}$ Including social fees.

\section{Healthcare costs}

The cost for each visit to the school nurse was estimated at $\$ 58$. The mean number of visits to the school nurse was estimated to 20,00 in the intervention group and 27,83 in the control group based on baseline values. The mean number of visits to the school nurse decreased by $10,75(-53,75 \%)$ in the intervention group, compared with baseline values. In the control group, the mean number of visits decreased by $6,89(-24,82 \%)$.

\section{Health effect}

After 20 months, the participants in the intervention group had increased their QOL by 0.08 units more than those in the control group $(P=.04)$ (Table 4$)$. The increase in the intervention group was greater than that in the control group at all follow-ups (Figures 2 and 3). Based on this data, gained QALY at 20 months was 0.10 $(P=.03)$.

\section{Cost-effectiveness}

The net costs per participant in the intervention group were $\$ 383$ at 20 months. Costs per gained QALY were $\$ 3,830$ after 20 months (Table 5).

The probability of cost-effectiveness when stakeholders are willing to pay 50,000 USD for a QALY [40] is 95\% (Figure 4).

\section{Discussion}

\section{Main results}

When considering the first 20 months, the ICER is $\$ 3,830$ per QALY. The dance intervention was shown to increase the QOL, which translated into a QALY gain of 0.10 after 20 months. In addition to an increase in QOL, sustained new healthy habits for this target group might prevent future psychiatric illness [41]. The aim of this analysis was not to evaluate which elements of the intervention that was important for the effect.

There is no official level of willingness to pay for a gained QALY in the United States, but $\$ 50,000$ and $\$ 100,000$ are often used [40]. In Sweden, an unofficial threshold of $\$ 75,000$ has been used to guide decisions about subsidized medicine [42]. The ICER of $\$ 3,830$ per QALY in this study is consequently well below that threshold. These results indicate that the dance intervention was valuable and an efficient use of healthcare resources in relation to what Western countries are willing to pay for a gained QALY.

Healthcare consumption, i.e. number of visits to the school nurse, was an uncertain factor. A test of the factor showed that there was a considerable gap between the number of visits reported by the girls and the number of visits found in the medical records. The school nurses expressed difficulties with the charting of social and mental health issues, due to lack of time, tradition, structure of the journal, and ethical considerations $[31,43]$. The self-reported visits were based on a retrospective open question which can be unvalid. Therefore, the ICER was calculated without these, giving an ICER of $\$ 6,700$. The sensitivity analysis also showed that the ICER was doubled $(\$ 7,660)$ when using $50 \%$ of gained QALY and $\$ 7,180$ when costs were assumed to be $50 \%$ higher than calculated, still well below the threshold value.

In this analysis, only savings for the School Health Services were considered. The larger increase in QOL in the intervention group may also have led to savings for other institutions such as primary care, youth centers, and the total Welfare Services in school. Since research has shown associations between internalizing problems in adolescence and in adulthood, it can also be assumed that the larger increase in QOL after the dance intervention could lead to further savings [44-46]. However, the present study was too small to be able to support this notion.

The girls included in the study were obviously exposed to outside influences in addition to the intervention. For example, periods of examinations in school may have increased feelings of stress and thereby affected the girls' general well-being. Since the intensity of school work varies during the school year, the 12-month follow-up can be considered the most important one.

Table 4 Treatment effect in QOL based on the HUI3 for intervention (I) and control (C) groups

\begin{tabular}{lll}
\hline & Baseline & 20 months, change from baseline \\
\hline Intervention (I) & $0.71(0.66-0.77)$ & $0.10(0.05-0.15)$ \\
Control (C) & $0.77(0.73-0.82)$ & $0.02(-0.05-0.08)$ \\
Difference I - C & $-0.06(-0.01-0.13)$ & $0.08(-0.16--0.01)$ \\
\hline
\end{tabular}




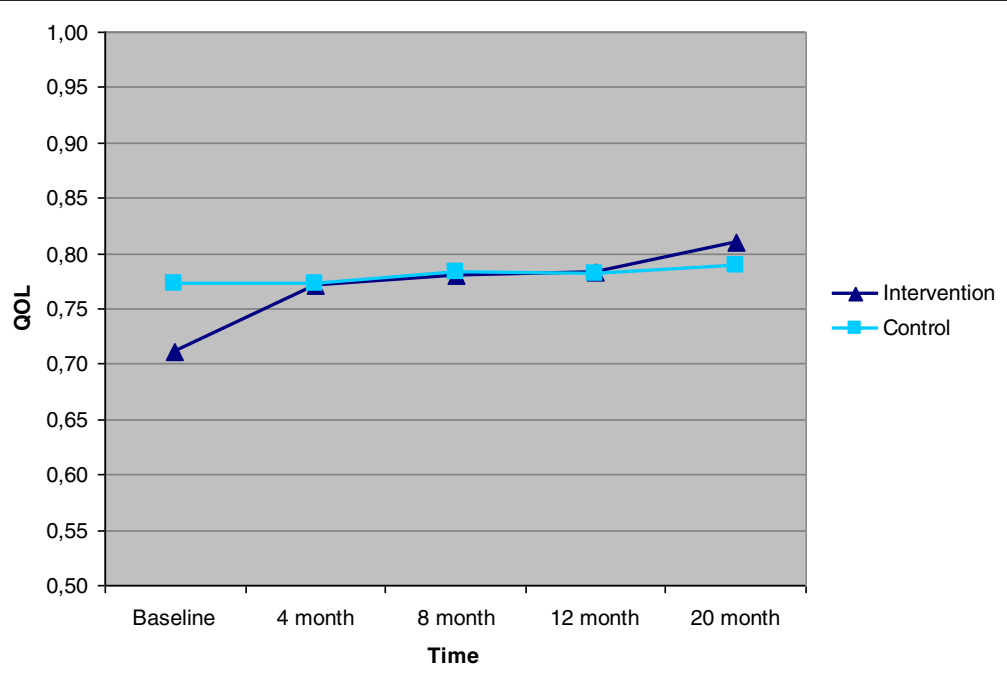

Figure $2 \mathrm{QOL}$, based on HUI3 for intervention and control groups.

\section{Strengths and weaknesses}

The economic evaluation was performed as a cost-utility analysis from a societal perspective, based on a randomized controlled trial. This method is adopted to find out how you can optimally allocate limited resources and is suitable when the aim is to compare different kinds of interventions. It is also a preferred approach for stakeholders compared with other common models $[26,47]$.

The HUI3 is a well recognized instrument, published in detail $[27,32,33,48,49]$, and providing a good estimate of utility values in a community-dwelling, relatively healthy, population. It has been developed by using preferences from a random sample of respondents 16 years of age and older and has also been used to measure health status in several studies on children [48].
However, a weakness is that the validity and reliability of the Swedish version of the instrument have not been tested. We did not agree with the translation in the official Swedish version of the word 'unhappy'. In the official version, 'nedstämd' (similar to lightly depressed) was used, but we chose to use what we believe is a more common expression among youth, 'olycklig' (similar to not happy or not glad).

A strength of this analysis is its long-term perspective. There is a great need for studies that establish the sustainability of interventions, to evaluate whether the effects can remain for a long period after the end of the intervention. In this case the 20-month follow-up was approximately a year after the last session of the intervention.

Extrapolation of the trial data was necessary. The last observation carried forward approach was used to

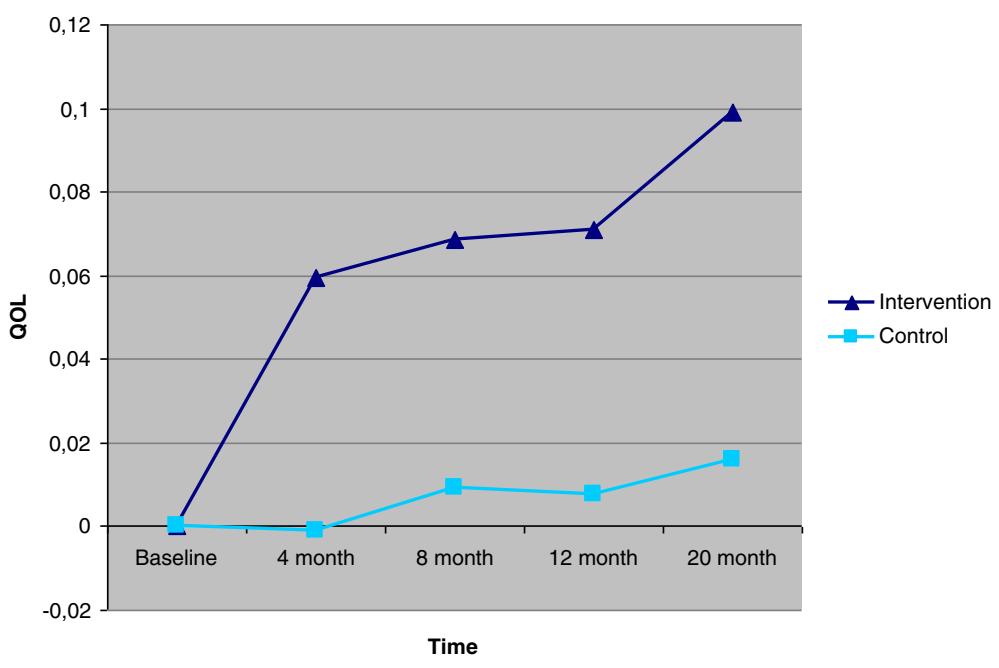

Figure 3 Change in QOL from baseline, based on HUI3 for intervention and control groups. 
Table 5 Results of cost-utility analysis for a 20-month period

\begin{tabular}{lr}
\hline Variable & After 20 months \\
\hline Gained QALY & $0.10(0.01-0.18)$ \\
Intervention costs & $670(570-770)$ \\
Savings in health care (compared to control group) & $287(-735-1310)$ \\
Net costs & 383 \\
Costs per gained QALY & 3830 \\
Costs per gained QALY (healthcare savings excluded) & 6700 \\
Costs per 50\% of gained QALY & 7660 \\
Cost per gained QALY with 50\% increased intervention costs & 7180 \\
\hline
\end{tabular}

handle missing data. This approach has been criticised in recent years for weaknesses in validity and estimations of the result $[37,39,50]$. Other methods were considered but the last observation carried forward approach was chosen since both groups in the study were feeling better after 20 months. Since the participants in the study in general showed an increase in QOL, it can be assumed that the results are more likely to be underestimated than overestimated, which some of the critics claim often is the case.

It cannot be ruled out that differences in QOL at baseline, despite not being significant, may have had an impact on the cost-effectiveness ratio. A lower value at baseline means a higher possible increase. Moreover, it cannot be ruled out that a control group with exactly the same QOL at baseline would have increased their QOL more than the control group in our study. Hence, some caution in interpreting the results is recommended.

Differences in gains of QOL between the intervention and the control group were 0.06 units at the end of the intervention and 0.08 one year later (follow-up at
20 months after start). Hence, a sustainable effect of the intervention seems to be possible, which would in that case give a lower ICER. However, we have not found any research which indicates for how long time the effect may remain. We don't think it is likely that the effect will end the day after the last follow-up. On the other hand, assumptions of very long-lasting effects may be an overestimation.

In the way the intervention was organized in this study, there were no costs for the participants. The dance hall was close enough to the participants' schools to not require any travelling costs. The girls in the intervention reported high enjoyment of the dance sessions [24]. This indicates that there might not have been any sacrifice, such as loss of enjoyment compared to an alternative activity, to participate in the dance sessions.

\section{Results in relation to previous research}

No economic analyses were found of dance as an intervention to prevent or treat internalizing problems. This analysis therefore seems to be filling a gap of knowledge.

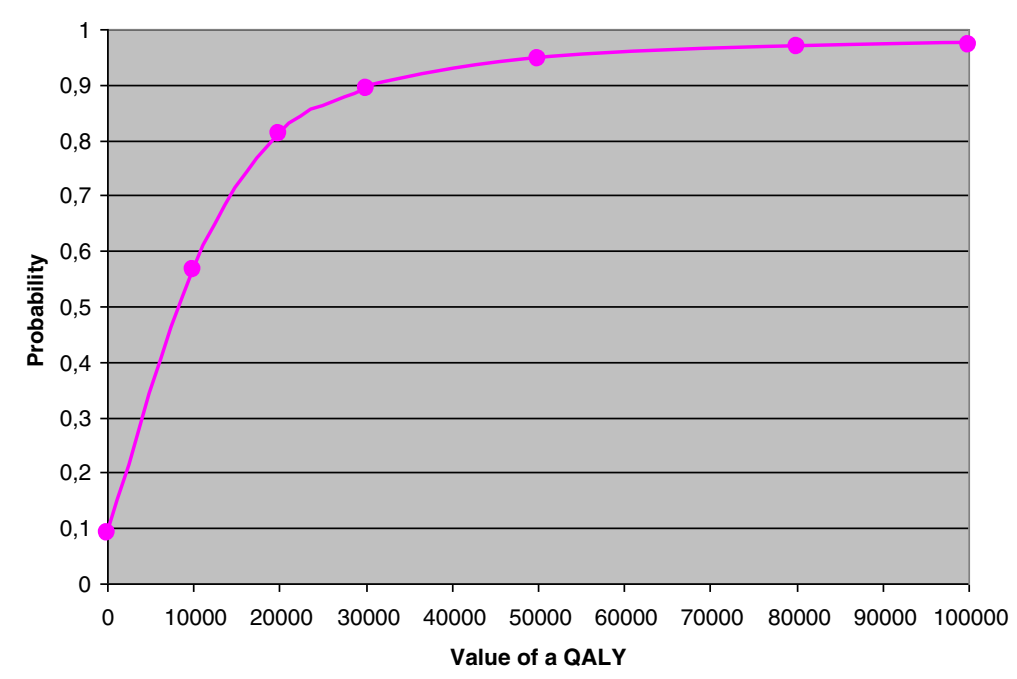

Figure 4 Probability of cost-effectiveness. Probability of cost-effectiveness using the HUI3 presented in a cost-effectiveness acceptability curve with 0, 10 000, 20 000, 30 000, 50 000, 80 000, and 100,000 USD as value of a QALY. 
The scarceness of evidence-based interventions for adolescent girls with internalizing problems may be due to the lack of studies as well as organizational complexity, with many institutions involved in prevention and care. However, the patient group is in great need of effective interventions.

\section{Further research required}

The present study evaluated the cost-effectiveness of an intervention with dance for adolescent girls with internalizing problems. Intervention studies and economic analyses of interventions for this target group is an unexplored research area, in great need of further studies. Specifically for this study, there is also a need to find out what the most important components of the dance interventions were.

The results of this research can support comparisons with other approaches to prevent or treat mental problems as well as with other modalities. The research also highlights the need for long-term research to establish the sustainability of this type of interventions.

The present study also revealed that there is a lack of research on the school health services in Sweden.

\section{Conclusions}

The present study shows that, for adolescent girls with internalizing problems, it can be cost-effective to complement the school health services with a dance intervention. The dance intervention was shown to increase QOL, and the increase remained 20 months after start. Costs per QALY were rather low and if you assume that the effect will remain over time, the ICER will be even lower.

\section{Abbreviations}

QALY: Quality-adjusted life-years; QOL: Quality of life; HUI3: Health Utility Index Mark 3; ICER: Incremental cost-effectiveness ratio.

\section{Competing interests}

The authors declare that they have no competing interest.

\section{Authors' contributions}

$A D, L H$ and MM drafted the concept and design of the study, and conducted the data collection. AD and MM designed the intervention. AP performed the health economic analysis. AP wrote the manuscript and AD assisted. LH provided health economic expertise, assisted in the economic evaluations, and supervised the writing, analysis and revision. All authors read and approved the final manuscript.

\section{Acknowledgements}

Financial support was provided by the research committee of Örebro County Council and the municipality of Örebro.

\section{Author details}

'Department of Community Medicine and Public health, Örebro County Council, P.O. Box 1613, Örebro SE-70116, Sweden. ${ }^{2}$ Centre for Health Care Sciences, Örebro County Council, Örebro, Sweden. ${ }^{3}$ School of Health and Medical Sciences, Örebro University, Örebro, Sweden.

Received: 26 June 2012 Accepted: 6 February 2013

Published: 20 February 2013

\section{References}

1. Janson S: Chapter 4. Children's and young people's health. Health in Sweden: The National Public Health Report 2001. Scand J Public Health Supp/ 2001, 58:103-116.

2. Petersen S, Bergström E, Cederblad M, Ivarsson A, Köhler L, Rydell A-M, Stenbeck M, Sundelin C, Hägglöf B: Barns och ungdomars psykiska hälsa i Sverige: en systematisk litteraturöversikt med tonvikt på förändringar över tid (Children and youths health in Sweden: A systematic review with emphasis on development over time). Stockholm: Kungl. Vetenskapsakademien, Hälsoutskottet; 2010.

3. Socialstyrelsen (The National Board of Health and Welfare): Folkhälsorapport 2009 (Public health report 2009). Stockholm: Socialstyrelsen (The National Board of Health and Welfare); 2009.

4. Statistikdatabas (Statistical database). http://192.137.163.49/sdb/par/resultat.aspx.

5. Socialstyrelsen (The National Board of Health and Welfare): Tänk långsiktigt!: en samhällsekonomisk modell för prioriteringar som påverkar barns psykiska hälsa. (Think in long terms!: a societal model for priorities that influence childrens mental health). Stockholm: Socialstyrelsen; 2004.

6. Churchill R, Hunot V, Corney R, Knapp M, McGuire H, Tylee A, Wessely S: A systematic review of controlled trials of the effectiveness and costeffectiveness of brief psychological treatments for depression. Health Technol Assess 2001, 5:1-173.

7. Barnpsykiatrikommittén (Commission of child psychiatry): Det gäller livet: stöd och vård till barn och ungdomar med psykiska problem: slutbetänkande. (It's about life: care and support to children and adolescents with mental problems). vol. SOU. Stockholm: Socialdepartementet (Ministry of Health and Social Affairs); 1998.

8. Statens Beredning för Medicinsk Utvärdering (Swedish Council on Health Technology Assessment): Metoder för att främja fysisk aktivitet: en systematisk litteraturöversikt: mars 2007 (Methods for promoting fysical activity: a systematic review: march 2007). Stockholm: Statens beredning för medicinsk utvärdering (The Swedish Council on Technology Assessment in Health Care); 2007.

9. Statens Beredning för Medicinsk Utvärdering (Swedish Council on Health Technology Assessment ): Program för att förebygga psykisk ohälsa hos barn: en systematisk litteraturöversikt (Programs for preventing mental problems among children: a systematic review). Stockholm: Statens beredning för medicinsk utvärdering (The Swedish Council on Technology Assessment in Health (are); 2010

10. Romeo R, Byford S, Knapp M: Annotation: Economic evaluations of child and adolescent mental health interventions: a systematic review. J Child Psychol Psychiatry 2005, 46:919-930.

11. Utredningen om prioriteringar inom hälso- och sjukvården (The health care priorities commission): Vårdens svåra val: slutbetänkande (Hard decisions for Health Care: Final Report). Stockholm: Fritzes; 1995.

12. Skollag 1985:1100, english version (Education Act). http://www.sweden.gov.se/ content/1/c6/02/15/38/1532b277.pdf.

13. Larsson B, Zaluha M: Swedish school nurses' view of school health care utilization, causes and management of recurrent headaches among school children. Scand J Caring Sci 2003, 17:232-238.

14. Socialstyrelsen (The National Board of Health and Welfare): Socialstyrelsens riktlinjer för skolhälsovården (The guiding principles for School Health Care from The National Board of Health and Welfare). Stockholm: Socialstyrelsen (The National Board of Health and Welfare); 2004.

15. Socialdepartementet (Ministry of Health and Social Affairs): Hälso- och sjukvårdslagen: 1982:763 (The health and medical services act). Stockholm: Svensk författningssamling; 2000.

16. Camacho TC, Roberts RE, Lazarus NB, Kaplan GA, Cohen RD: Physical activity and depression: evidence from the Alameda County Study. Am J Epidemiol 1991, 134:220-231.

17. DiLorenzo TM, Bargman EP, Stucky-Ropp R, Brassington GS, Frensch PA, LaFontaine T: Long-term effects of aerobic exercise on psychological outcomes. Prev Med 1999, 28:75-85.

18. Jerstad SJ, Boutelle KN, Ness KK, Stice E: Prospective reciprocal relations between physical activity and depression in female adolescents. J Consult Clin Psychol 2010, 78:268-272.

19. Eyler AA, Brownson RC, Donatelle RJ, King AC, Brown D, Sallis JF: Physical activity social support and middle- and older-aged minority women: results from a US survey. Soc Sci Med 1999, 49:781-789.

20. Barr-Anderson DJ, Young DR, Sallis JF, Neumark-Sztainer DR, Gittelsohn J, Webber L, Saunders R, Cohen S, Jobe JB: Structured physical activity and psychosocial correlates in middle-school girls. Prev Med 2007, 44:404-409. 
21. Kuo J, Schmitz KH, Evenson KR, McKenzie TL, Jobe JB, Rung AL, Gittelsohn J, Pate RR: Physical and social contexts of physical activities among adolescent girls. J Phys Act Health 2009, 6:144-152.

22. Grönlund E, Renck B: Dansterapi för deprimerade tonårsflickor samt utvärdering av det samlade dansterapiprojektet (Dance therapy for depressed adolescent girls and evaluation of the dance therapy project). Stockholm: Nämnden för konstnärligt utvecklingsarbete, Danshögskolan (The committe for artistic evolution work, University of Dance); 2006.

23. Burgess G, Grogan S, Burwitz L: Effects of a 6-week aerobic dance intervention on body image and physical self-perceptions in adolescent girls. Body Image 2006, 3:57-66.

24. Duberg A, Hagberg L, Sunvisson H, Möller M: Influencing Self-rated Health Among Adolescent Girls With Dance Intervention. JAMA Pediatrics 2013, 167(1):27-31.

25. Metodbok för skolhälsovården (Methods for School Health Services). http:// www.orebroll.se/sv/uso/Patientinformation/Kliniker-och-enheter/Barn-ochungdomskliniken/Skolhalsovard/Metodbok/.

26. Drummond MF: Methods for the economic evaluation of health care programmes. 3., [updated and rev.] ed. Oxford: Oxford University Press; 2005.

27. Horsman J, Furlong W, Feeny D, Torrance G: The Health Utilities Index (HUI): concepts, measurement properties and applications. Health Qual Life Outcomes 2003, 1:54.

28. Lönestatistik (Wage statistics). http://www.lonestatistik.se/loner.asp/yrke/ Danslarare-2256.

29. Örebro Kommun (Municipality of Örebro): Hyror och avgifter vid hyra av lokaler och idrottsanläggningar (Rents and fees for sports facilities). Örebro: Örebro Kommun (Municipality of Örebro); 2012.

30. Lönestatistik (Wage statistics). http://www.lonestatistik.se/loner.asp/yrke/ Skolskoterska-1949.

31. Skoglund I: Skolhälsans verksamhetsberättelse Läsåret 2009/2010 (Annual report for School Health Services school year 2009/2010). Örebro: Skolhälsovårsenheten (School health services); 2010.

32. Feeny D, Furlong W, Torrance GW, Goldsmith CH, Zhu Z, DePauw S, Denton M, Boyle M: Multiattribute and single-attribute utility functions for the health utilities index mark 3 system. Med Care 2002, 40:113-128.

33. Furlong WJ, Feeny DH, Torrance GW, Barr RD: The Health Utilities Index (HUI) system for assessing health-related quality of life in clinical studies. Ann Med 2001, 33:375-384.

34. Tambour M, Zethraeus $\mathrm{N}$, Johannesson M: A note on confidence intervals in cost-effectiveness analysis. Int J Technol Assess Health Care 1998, 14:467-471.

35. Willan AR: Analysis, sample size, and power for estimating incremental net health benefit from clinical trial data. Control Clin Trials 2001, 22:228-237.

36. van Hout BA, Al MJ, Gordon GS, Rutten FF: Costs, effects and C/E-ratios alongside a clinical trial. Health Econ 1994, 3:309-319.

37. Mazumdar S, Liu KS, Houck PR, Reynolds CF 3rd: Intent-to-treat analysis for longitudinal clinical trials: coping with the challenge of missing values. J Psychiatr Res 1999, 33:87-95.

38. Hamer RM, Simpson PM: Last observation carried forward versus mixed models in the analysis of psychiatric clinical trials. Am J Psychiatry 2009, 166:639-641.

39. Woolley SB, Cardoni AA, Goethe JW: Last-observation-carried-forward imputation method in clinical efficacy trials: review of 352 antidepressant studies. Pharmacotherapy 2009, 29:1408-1416.

40. Shiroiwa T, Sung YK, Fukuda T, Lang HC, Bae SC, Tsutani K: International survey on willingness-to-pay (WTP) for one additional QALY gained: what is the threshold of cost effectiveness? Health Econ 2010, 19:422-437.

41. Rothon C, Edwards P, Bhui K, Viner RM, Taylor S, Stansfeld SA: Physical activity and depressive symptoms in adolescents: a prospective study. BMC Med 2010, 8:32.

42. Tandvårds- och läkemedelsförmånsverket TLV (The Dental and Pharmaceutical Benefits Agency). http://www.tlv.se/.

43. Clausson EK, Kohler $\mathrm{L}$, Berg A: Ethical challenges for school nurses in documenting schoolchildren's health. Nurs Ethics 2008, 15:40-51.

44. Cederblad M: Från barndom till vuxenliv, en översikt av longitudinell forskning (From childhood to adulthood, a review of longitudinell research). Stockholm: Förlagshuset Gothia; 2003.

45. Kinnunen P, Laukkanen E, Kylma J: Associations between psychosomatic symptoms in adolescence and mental health symptoms in early adulthood. Int J Nurs Pract 2010, 16:43-50.

46. Ljungdahl S, Malmgren L, Bremberg S: Lindriga psykiska symtom och risk för psykisk sjukdom: en systematisk litteraturöversikt (Mild psychiatric symtoms and risk for psychiatric diseases: a systematic review). Stockholm: Statens folkhälsoinstitut (National institute for Public Health); 2007.

47. Phillips CJ, Fordham R, Marsh K, Bertranou E, Davies S, Hale J, Kingsley M, Parke S, Porteous C, Rance J, Warm D: Exploring the role of economics in prioritization in public health: what do stakeholders think? Eur J Public Health 2011, 21:578-584.

48. Feeny D: The Health Utilities Index: A Tool for Assessing Health Benefits. PRO Newsletter 2005, 34:2-6.

49. Feeny D, Huguet N, McFarland BH, Kaplan MS: The construct validity of the Health Utilities Index Mark 3 in assessing mental health in population health surveys. Qual Life Res 2009, 18:519-526.

50. Blankers M, Koeter MW, Schippers GM: Missing data approaches in eHealth research: simulation study and a tutorial for nonmathematically inclined researchers. J Med Internet Res 2010, 12:e54.

doi:10.1186/1478-7547-11-4

Cite this article as: Philipsson et al:: Cost-utility analysis of a dance intervention for adolescent girls with internalizing problems. Cost Effectiveness and Resource Allocation 2013 11:4.

\section{Submit your next manuscript to BioMed Central and take full advantage of:}

- Convenient online submission

- Thorough peer review

- No space constraints or color figure charges

- Immediate publication on acceptance

- Inclusion in PubMed, CAS, Scopus and Google Scholar

- Research which is freely available for redistribution

Submit your manuscript at www.biomedcentral.com/submit
C Biomed Central 